\title{
$[10]$
}

\section{Interpreting American Litigiousness}

\author{
Carol J. Greenhouse
}

Sooner or later any discussion of the role of law in the United States turns to the question of the litigiousness of Americans. Litigiousness is widely held to be an American trait, not only by allegedly less litigiousness foreigners but also among Americans themselves. This chapter is about Americans' concerns with litigiousness. I treat these concerns as a cultural self-representation of American society. Litigation is an important activity in its own right, but it is the concerns of Americans about litigiousness that is the subject of what follows. My starting point is in the observation that many Americans are ready to believe in, almost to the point of insistence, their own allegedly litigious national character, even when evidence for this characterization is absent, ambiguous, or contradictory. ${ }^{1}$

${ }^{1}$ Galanter 1983 persuasively reviews this evidence. He questions the widespread criticism that Americans express for "hyperlexis"-excessive use of the law. Engel's study of "Sander County" begins with the observation that "although it is generally acknowledged that law is a vital part of culture and of the social order, there are times when the invocation of formal law is viewed as an antisocial act and as a contravention of established social norms" (Engel 1984:549; emphasis in the original). Engel suggests that popular concern with litigation "can . . . draw our attention to important underlying conflicts in cultural values and changes or tensions in the structure of social relationships" (ibid., p. 550). This chapter pursues that theme. 


\section{Talking about Litigiousness}

How do Americans talk about litigiousness? How does this term convey meaning? How are the meanings of litigiousness learned? Who is their audience? A first step toward addressing these questions is in examining the discourse surrounding litigiousness, a discourse widely shared by American academics, practitioners, and laypeople alike (Galanter 1983:5-11). ${ }^{2}$ Its features can be summarized in the following way:

1. Scale. The adjective "litigious" is generally applied to groups rather than individuals; it is used in reference to a collective phenomenon. Thus, an ordinary usage would be "Americans are litigious," not "my neighbor is litigious." One's neighbor might be a troublemaker or a bad neighbor, but not, in ordinary American speech, litigious. The referents of this adjective are virtually always the third-person plural. The open-ended, collective referent of the term suggests that its scale is that of American society itself, or the American social fabric. This scale suggests that when people express concern about litigiousness they are concerned that some defect exists in American culture or social structure.

2. Value. Litigiousness carries negative connotations. Why this should be so is part of the subject of this chapter; that it is so is widely understood. Later we will be exploring two features of this negative value: the connection between litigiousness and disputing, and the connection between litigiousness and appeals to authority.

3. Orientation. Concern with litigiousness is process-oriented not result-oriented. Thus, while opening floodgates for new classes of litigation might result in positive social change, the talk about litigiousness focuses instead on the use of the legal process itself, as if use equals abuse.

4. Temporality. "Litigiousness" carries with it an adverbial aura, because those who comment on it generally make assumptions about the

2Some examples of the extensive commentary on litigiousness include the following: "[Americans have] an almost irrational focus - virtually a mania-on litigation as a way to solve all problems" (Chief Justice Warren Burger, quoted in Newsweek, November 21, 1983). (Litigation seen as abnormal.) "We've gotten to the point where there are just plain silly suits" (John Cibinic, Jr., Professor of Law, George Washington University, quoted in Business Week, May 28, 1984). (Litigation seen as parody.) "While something intractable in the American character may make us such a contentious lot, the national obsession with litigation has clearly reached ridiculous proportions. Court suits are increasing six times faster than the population, and each year state courts alone report more than 13 million new civil cases" (Washington Monthly, June 1983). (Litigation seen as unnatural.) 
direction of social transformation with respect to court use. People who worry about litigiousness worry about its increase; the mythology holds that Americans were once able to resolve disputes without major recourse to courts but can no longer manage to accomplish the business of personal life without judicial intervention (e.g., Nelson 1981).

5. Textuality. Finally, litigiousness seems to be understood as constituting social commentary. Talk about litigiousness centers on how to "read" it for messages about the state of society. Engel's (1984) study suggests that Americans "read" different categories of litigation differently. Ethnographic evidence (developed below) from the United States shows that litigiousness is popularly understood as a symbol of important social characteristics. These interpretive efforts are at the heart of the larger problem this chapter addresses.

These five dimensions help focus the following discussion on a few interrelated problems that converge in the question of how and why litigiousness functions so effectively as an element of the semiotics of social experience in the United States. Specifically, what relationships does litigiousness symbolize? And how is it that, in the eyes of so many Americans, litigiousness signals something negative about American society?

We begin with ethnohistorical data from the United States. The case study is built around an ethnographic problem: In the American town I call "Hopewell," Baptists express a strong aversion not only to litigiousness but also to litigation and every other adversarial form of disputeprocessing. Southern Baptists in Hopewell are by no means an extreme sect; they are sophisticated suburbanites who in most ways live much like their neighbors. (This fact distinguishes Hopewell's Baptists from the Amish, who proscribe litigation for other reasons; see Hostetler 1984.) The Hopewell Baptists are white, educated, and affluent. Like most Americans, they do not use the court, which is readily accessible, Hopewell being the county seat. Unlike the majority of Americans, however, Baptists in Hopewell explain their avoidance of the court and of disputing altogether in religious terms, which are explained in the next section (for a full account, see Greenhouse 1986a).

The heart of the following case study involves a comparison between Hopewell's Baptists and another dominant local social faction during the middle third of the nineteenth century. At the time, Baptists were forming a symbolic equation between harmony and Christianity. The other faction, meanwhile, was developing new uses of the judicial system. Specifically, while the Baptists were framing their proscriptions of 
conflict in terms of the contradictions between appeals to human authority and Christian faith in Jesus, the local judicial system was increasingly monopolized by relatively few actors. Both processes reached a climax between 1858 and 1868. I must stress the local aspect of this discussion, because the connection between these two groups had to do with local responses to the vectors of political controversies in the state, the region, and the nation.

\section{Attitudes toward Conflict in Hopewell}

My fieldwork, from 1973 to 1975 and again in 1980, was in the small metropolitan suburb I call Hopewell, Georgia. I shall summarize the findings of that research (Greenhouse 1982a, 1982b, 1983, 1986a, and 1986b).

Baptists in Hopewell place special importance on the inappropriateness of disputing for Christians. ${ }^{3}$ Their rejection of disputing is based on scriptural exhortations to "turn the other cheek," to yield what is demanded, and most important, to leave all judgments to Jesus. The result of this ethic is a pattern of conflict resolution that centers on indirection; prayers, jokes, narratives, or simple avoidance hint obliquely at the issues that divide people. Local Baptists place a great deal of importance on the spiritual significance of their restraint as well as on the significance of its absence among non-Baptists, whom they assume to be contentious and litigious-and damned.

The proscriptions-felt and urged, more than enforced-against overt adversarial conflict have a particular character-for example, church members encourage one another to abjure only some conflicts, conflicts within the circle of the church membership, family, and friendship. Feelings of conflict with non-Christians (i.e., the unsaved) are not exactly encouraged, but they are actively relevant to Baptists' sense of their distinctive social and moral identity. For example, Baptist teenagers in Hopewell are urged to avoid their peers' habits of drinking, dancing, and-until they are deemed ready for serious courtshipdating as couples. The effect is that friendship networks among youth

\footnotetext{
${ }^{3}$ At several points in this chapter, I stress the local nature of my findings. This must be one of them. Baptist communities elsewhere have been described by Batteau 1982, Bryant 1980, and Peacock 1975; these do not show the same aversion to confrontative interaction that I describe here. This chapter is in part an attempt to show why Hopewell used a religious idiom to address fundamental political questions.
} 
tend to be based in Hopewell and to center in the Baptist church, even if the young people attend school or work elsewhere. This segregation is viewed positively.

While feelings of conflict can have this morally and socially positive side, Baptists draw a sharp line between such sentiments and overt disputing. In Hopewell, many Baptists explained to me that disputing is a profoundly unchristian act because the Bible states clearly that Jesus is the judge of all people. The implication seems to be that to enter into a dispute is to stand as judge over another person, and to do so not only reveals lack of faith in Jesus, but preempts Jesus' power ("All vengeance is mine . . . saith the Lord"). Another related dimension of this proscription is the Baptists' premise that Christians have no need to press their own interests in any context because God has all human needs in mind. A frequent theme in sermons was that of proper Baptist prayerwhich should always give thanks, rather than make requests or offer contracts in the form of vows. Finally, since Baptists are convinced that non-Baptists live lives of constant carping and turmoil, they extend their own principle of the "life of good witness" (the preferred form of evangelism in Hopewell) to their abstinence from disputing. All these factors lead Baptists in Hopewell most frequently to withdraw from conflict situations that seem likely to result in a dispute.

On another dimension, Baptists acknowledge that disputing and "making a case for oneself" is a strong temptation in everyday life, and they present their own assiduousness in avoiding disputes as the product of concerted effort buttressed by prayer. That Baptists see the temptation to dispute as one component of their continuing need for salvation is some measure of the large role they give prayer in ordering their private lives. Indeed, prayer is a vital part of private and public life among Baptists in Hopewell. In church, among friends, at the dinner table, on the telephone-prayer is public. In addition, an individual's private prayer life is potentially virtually constant. A housewife may recount having knelt alone by a chair or by the bedside for a moment of prayer, but prayer does not require any physical interruption of the day's activity. Prayer is a form of narrative that accompanies the performance of everyday activities or, more accurately from the Baptist perspective, inserts some textuality into the looming chaos of "the world" ("the world" refers specifically to a society dominated by the unsaved, until the Day of Judgment). Prayer is verbal and is addressed directly to Jesus ("So I said to the Lord, 'Lord . . ." was the beginning of many prayer narratives I heard in conversation). The most frequent themes of prayers 
narrated to me were pleas for Jesus' support in refraining from disputing and from having feelings of conflict within a family or friendship group, and prayers for the salvation of some particular individual. Prayers for interpersonal harmony consist of potentially lengthy explanations, spoken aloud or verbalized silently, of the history of the conflict.

While prayer is held to be adequate for the faithful as a means of achieving order in their personal lives, Baptists acknowledge the difficulties of accomplishing harmony for people with stunted, misdirected, or absent "prayer lives." The law, they say, helps these people live in peace. It is only in this sense- of making the world of the unsaved safethat the Baptists in Hopewell concede any valid place to the law. Manmade law (they stress "man-made") is by definition a conceit, because it is not the law of God. It is important to note that Hopewell's Baptists do not conceive of God's law as a set of rules (Greenhouse 1982a); they do, however, understand man-made law as rules. God's law-the central tenets of the Christian life-are individually felt. This is part of the significance of the Baptists' insistence that the Scriptures are accessible to all Baptists by virtue of their faith, but that the "Christian life" is reason itself. The contrast to the world of rules, lawyers, judges, and (in Baptist eyes) the exaltation of contention could not be clearer: where God's law is felt, man's law is imposed; where God's law is reason itself, man's law is artificial; where God's law promises eternal life, man's law thrives on enmity and conflict; where God's law is expressed in prayer, man's law is expressed in rules. Under God's law, all people are equalall people become equal, shedding the inequalities (particularly the ultimate vanity of basing status on material possessions) that Baptists see in the non-Baptist world.

Thus, like other Americans, Baptists in Hopewell see their own way of life as by definition legal, although they carefully locate its legality in reason, the source of which is God, and in nature, which is understood as God's dominion. ${ }^{4}$ The Baptists' vision of social order, which comes about by extending God's word to the unsaved, is a vision of a society at peace because each individual "does right" and "knows right in his heart." Authoritative intervention is not necessary to the achievement of this order, although Hopewell Baptists do concede a role for the law in the interim period before Judgment Day. In this world view, litigiousness is

${ }^{4}$ Hopewell's Baptists reject both the asceticism of the Primitive Baptists and what they see as the sensual excesses of the unsaved on these grounds; both rejections are based on the principle of the healthy normality of physical appetites, within reason. 
a sign of "the world," proving the need for salvation again and again on a large scale.

While Hopewell's Baptists might resist the drawing of parallels between their stance toward the world and that of other Americans, those parallels are apparent. First, it is important to note that, like the Baptists, most Americans have no experience with litigation. While most adult Americans have consulted a lawyer once, the vast majority of those consultations are over the administration of a mortgage or a will; although I had no means to gauge the recourse of Baptists to lawyers for these purposes, I never heard them proscribed. ${ }^{5}$ Second, Baptists' attitudes toward the legal quality of society are not substantially different from those of other Americans, although the social maps of Baptists might differ. (This point will be taken up in a later section.) Hopewell Baptists "read" litigiousness as an index of society's ultimate formation; they feel that use of the official law violates an ordained equality among citizens and believers. Like other Americans, Hopewell Baptists share in the consciousness of the liberal state and its long heritage in Western culture. Baptists are not ambivalent about official law and its relationship to the "natural" legality of social life, but this is a difference only of degree from the more general attitude outlined earlier.

\section{Conflicting Signs}

Modern Baptists in Hopewell are confident in their rejection of conflict, disputing, and litigiousness on theological grounds, but while deeply held, their beliefs appear to be the product of a very different stance in the early days of the county's history (Greenhouse 1986b). In the years between the first organization of the Baptist church in Hopewell (1824) and the Civil War (1861), the local Baptist leadership actively sought to eliminate conflict from the churches by interpreting it as unchristian. It is interesting to know why and how they accomplished this strategy. Briefly, they sought to eliminate the church's role as a forum for disputing so that the church could survive the deep political divisions of the day-states' rights, Cherokee removal, and abolition. The church in Hopewell was apparently deeply divided over these questions, and at one point its membership may have fallen to as low as seven. At this period in Hopewell's history, survival of the order de-

5There is recent documentation of Americans' uses of the law in Curran and Spalding 1974 and in Galanter 1983. 
manded that the church somehow transcend, or at least contain, politics. It finally did so by stressing its theological objections to the human authority that would be inescapably constituted in any overt dispute. By reiterating the contradictions between God's law and human authority over a period of twenty or more years, the local Baptist church association was finally successful in symbolically linking conflict with the unsaved. The Civil War marked an end to any mention of disputing in the church record, and the life of good witness became doubly that of the aspiring Baptist and the defeated Southerner.

But then as now, Hopewell was a diverse community, by no means entirely Baptist and by no means controlled by the Baptist world view. The withdrawal of Hopewell Baptists from conflict situations was above all a strategic local response to the political crosscurrents of their times. Baptists were not only a religious minority in Hopewell, as they are now, they were also a political minority on every significant issue of the day. The county applauded Cherokee removal; the Baptists lamented it. The county was strongly populist; the Baptist leadership, locally, came from the more aristocratic regions of Georgia. The South generally built its cause on antiabolitionism and states' rights; the local Baptists (but not, it is important to note, the Southern Baptist Convention) supported states' rights only. Against this shifting background of opposing and realigning forces, the Baptists in Hopewell forged their new semiotics of Christian harmony out of a combination of scriptural symbols and American political logic.

It would be an error to suppose that in signaling human authority as the agency of the undoing of God's law, Hopewell Baptists were responding in purely theoretical terms to a problem of theology. For them, human authority had faces and names over and above its generic meanings. Who were the Baptists' neighbors, and can we find a seam connecting the emergent Baptist symbolism and the responses of non-Baptist Hopewell to the same issues? Let us turn to the institution that was the object of the Baptists' reproach-the court. If we can discern who was using it, and how, perhaps we can sharpen the sense of context surrounding the question of how local Baptists interpret law use, and why.

Hopewell acquired three courts when the county of which it is the seat was founded in 1858. The area had been settled by whites since the 1820s, but it was incorporated as Hopewell, seat of the new Hopewell County, in the later year. The Court of Ordinary (for probate matters) and the Inferior Court had strictly local jurisdiction, but the Superior Court formed part of a judicial circuit that included several other coun- 
ties to the north, west, and south. It is interesting to note that the boundaries of the circuit, established by the Georgia legislature in 1833 and expanded with the establishment of contiguous counties, followed the same boundaries as the voting blocs in the legislature that had formed over the establishment of Hopewell County. The establishment of Hopewell County had been proposed by J. T. Smithson (another pseudonym), of neighboring "Lynette" County (to the west). His bill passed by a comfortable margin, but the nay votes clustered together in the wide swath of aristocratic counties to the east. (Phillips [1968] offers a clear description of Georgia state politics at this period.) Thus, it appears that the legislature took political alliances into account in forming the judicial districts. ${ }^{6}$

The setting of the boundaries around the Superior Court circuit united Hopewell County with its populist parent county, from which it had been formed. The political elite of Lynette County moved to Hopewell, where they continued in prominence as state senators and representatives and as founders of the Methodist church, among other activities. The Baptists in Hopewell, who had settled in the area earlier, came from "Harold" County to the east. Harold County, Hopewell's other "parent," was on the western frontier of the aristocratic counties; its dominant political party, plantation agriculture, slaveholding, and higher levels of affluence tied Harold to its lowland neighbors to the east. The net effect of the Superior Court's jurisdictional boundaries, then, was to divide local Baptists from their closest kin and friends. It is perhaps significant that the local Baptist church association included both Hopewell and Harold counties. In short, the Superior Court circuit was constituted geographically in a way that might predictably alienate Baptists, not on any doctrinal grounds but on grounds of origins and sympathies.

In 1858 the Superior Court met twice a year in each county of the circuit. Judges were required under the state constitution to be resident in the circuit, but during the period of concern at this point in our discussion (1858-68), the local circuit chief judges do not appear to have been resident in Hopewell County. ${ }^{7}$ It seems likely that the local Supe-

\footnotetext{
${ }^{6}$ An alternative would have been to follow congressional districts, which put Lynette (populist, to the west), Harold (aristocratic, to the east), and Hopewell (between them) in one unit. This grouping may explain why nineteenth- and early twentieth-century elections were often extremely close-a "seesaw" in the word of one Hopewell citizen.

${ }^{7}$ It is difficult to know the residence of the judges, but my extensive collection of local genealogies does not include the names of the Superior Court judges. The Inferior and Ordinary Courts, on the other hand, draw entirely on local families.
} 
rior Court judges were literally outsiders, as well as political outsiders from the Baptists' perspective.

Finally, Superior Court judges were elected under the state constitution for three-year terms. In 1861 a new constitution gave the power of appointment to the governor, and terms were extended to four years. Georgia's governors were Democratic after 1857, when J. E. Brown was elected, but the war years and the early years of reconstruction were a turbulent period for the governor's office. The state constitution of 1877 partially returned the selection of judges to the people (by having the state legislature elect them), but in the interim Georgia's governors were highly compromised in the eyes of those who had been loyal to the Southern cause. During the years when the Superior Court came to Hopewell and the power of appointment was most concentrated in the governor's hands, the Baptists in Hopewell conclusively defined impositions of human authority as alien to God's kingdom.

People in Hopewell would have been well aware of these developments in the judiciary, because each political party had its own local partisan newspaper. Other sources indicate the extent to which the local population were engaged in politics-for example, one minister complained in his diary that the congregation was too involved in debate on the church lawn to come inside for the sermon. Election-day riots were regular occurrences. It certainly was a turbulent period.

Even if the structure, composition, and selection of the Superior Court did not directly concern local people, the way their neighbors used it did. One modern commentator from Hopewell lightheartedly described the continual striving between the "ins" and "outs" as a seesaw, as closely matched forces battled for office at the local level. Close elections were the norm, and his evidence suggests that party faithful used whatever means they could to secure the ballot. Among these means was the Superior Court, where local political contests often had their last round, as one side or the other would have the other arrested on riot charges and brought to trial. Indeed, during the period before the Civil War, the docket of the Superior Court reads as a local roster of politically active men, all locally prominent.

Because the court sat only twice a year, it is not surprising that local people developed their own patterns of self-help. The court's role seems to have been one of validation, affirming the self-appointed efforts at social control from one side or the other. In a very different urban and historical context, Merry (1979) shows that modern Americans' use of the court in contexts of dispute is similarly directed largely at attempts to validate or authorize self-designed solutions to conflict. The contributors 
to Tomasic and Feeley's (1982) volume on "neighborhood justice" amplify a portrait of Americans using the court and other public agencies as instruments of self-help. Later we will consider the possible significance of this apparent continuity in the way Americans use the official law.

After the Civil War, patterns of court use in Hopewell did not change dramatically, except for a notable increase in cases of debt. One strategy to avoid the court's collection efforts was first developed by J. F. Smithson (this man was politically active, regionally prominent, and an experienced litigant from several charges of riot). Smithson failed to appear, he explained persuasively to the court later, because the presence of federal troops in the area and the general destruction around Hopewell had led him to believe that the court would not sit. Similar strategies were used later by Smithson's friends and eventually by clients of Smithson's law practice. Smithson was one of the two wealthiest men in the county in 1860 , when the census reported property, and his successful attempts to avoid paying local creditors after the war probably met with mixed reaction.

While the Superior Court was used to validate self-help solutions to problems among relatively few "repeat players" (Galanter 1974) in Hopewell, the Court of Ordinary provided a stark contrast. While it is possible that "settlements" there had been negotiated in advance, the refrain of those records in this period is "There being no disagreement . . ." or "There being no dispute . . ." to questions of the administration of wills, guardianship, and the distribution and sale of estates. The transfer of property from one side of a family to another and from one generation to another occurred publicly and smoothly through this court. It was a forum not only for men, who are the sole recorded Superior Court litigants in this period, but also for women and children to make their pleas concerning the disposition of a dead kinsman's affairs.

The contrast to the Court of Ordinary suggests that if the emergent doctrine of Hopewell Baptists had secular referents in the judiciary during this period, they were in the Superior Court (the Inferior Court was largely concerned with county administration). While the evidence is indirect to varying degrees, we can see that the public role of the court was to provide a forum for local political confrontation and, if Smithson's litigation is indicative, for personal gain. This is not to say that the court itself was corrupt, but its use was monopolized by litigants who designed a participatory role for the institution by manipulating complaints and defenses in strategic ways. Indeed, Baptists today condemn not the 
courts but the plaintiffs, although none of these historical developments is remembered. For Hopewell's Baptists a century ago, it is plausible to conclude that they saw the court as an arena in which the faction with which they were most at odds performed political dramas before strangers, for their own ends.

This section has given some faces and social identity to the institutional forms and authoritative agents whom the Hopewell Baptists conclusively rejected as being unchristian. The crucial period is the decade before, during, and after the Civil War, when the regional issues and divisions (Cherokee removal and other sectarian conflicts) gave way to the national issue of the Union's survival. The church records never name or otherwise identify the sources or issues of the disputes they were so concerned with effacing; their consideration of conflict is in purely "generic" terms. By rejecting disputing as a genre, the church leaders were able to replace it with another one: the genre of God's law. In establishing these genres of social discourse-the one to be rejected and other to endure-the local Baptists drew on the symbols they had available to them: the imagery of the American Revolution-individualism, equality, and freedom-and the imagery of the Bible. They did not have to reach very far to find their symbolism; it was all around them in the Protestant idiom of the American philosophical mainstream (see, e.g., Wills 1979) with its strong natural-law bias.

Litigants were moved by other strains of the same general philosophy. They had every reason to identify with the courts. In Hopewell the group most frequently in court was precisely the same group that had been instrumental in the establishment of the county in 1858 and had gerrymandered its boundaries to include the residences of leading members. Their control of the political process, in the legislature, in the courts, and in more private settings, made litigation an effective and predictable course of action for them. They too demonstrate their natural-law bias in merging the judicial branch with the legislative and using both as arenas for long-standing political contests. These were populists who drew heavily on the imagery of democracy and local control.

\section{Law as a Cultural Category in the United States}

The case study of emerging meanings of litigation and litigiousness in Hopewell in the nineteenth century illustrates the nature and context of one group of Americans' concern with litigiousness. This context was one 
of developing factionalism in a community profoundly, if ambiguously, divided on major contemporary controversies. While the populists were cementing their local position by creating Hopewell County, controlling its temporal affairs, and monopolizing the judicial system in strategic ways, the Baptists were articulating and defending an ideology that equated harmony with Christianity. In Hopewell, these two positions referred both to each other and to the wider philosophical currents of the time. The case study suggests that the position of the local Baptists, who equated litigiousness with the very undoing of God's order, was constructed of signs that pointed to the community of Hopewell. The local Baptist view of conflict and conflict resolution was thus directly tied to the local situation, in which the populists threatened-in the Baptists' eyes-an unwarranted hegemony, or at least an unwanted confrontation. Hence, the Baptists focused on the adversarial nature of conflict, on devaluation of plaintiffs' stances, and above all, on the inappropriateness of interventions of human authority in relationships that are supposed to be between equals.

The argument so far is not that the Baptists "invented" a legal ideology to separate their forces from those of the litigious group, for whom they felt distrust or antipathy on various grounds. The problem is constructed the other way around: in experiencing a need for social distance, Baptists focused on litigiousness and the problematic aspects of human authority as a symbolic resource. Why? This resource was available to them in practice (in the institutionalization of the local courts) in the mid-nineteenth century. Furthermore, this was a time of great local tension and widening distance among local factions. But these factors alone could not have shaped local Baptist political discourse; the wider cultural context made that discourse available. Specifically, the antiauthoritarian sentiment enshrined in the American Revolution channeled questions of difference and distance into questions of conflict, control, and hierarchy. The Baptist prescriptions for avoidance can be read as prescriptions for egalitarianism; this is one example of the impact of revolutionary logic on American social thought.

To generalize from this case study, therefore, we should look not to other Baptists' ideas about law, but to modern Americans' patterns of rejecting forms of discourse that illuminate the potential for hierarchy in relationships presumed to be equal. In their lamentations about litigiousness, Americans resist the capacity of the law to create these forms of discourse. Let us shift now from Hopewell's Baptists to the United States more generally.

Anthropological research on the United States suggests two ap- 
proaches to the question of how litigiousness acquires its significance as a cultural sign. The more general suggestion comes from Schneider (1968, 1977) and Perin (1977), who interpret American concepts of law as cultural references to a whole, ordered social life. Schneider's analysis of American kinship is built on cultural categories elicited from interviews: blood (descent) and law (marriage) are the warp and weft of the familial fabric. In placing the marrige promise-a contract-at the foundation of the family, Americans also provide the foundations of society itself, since, as Tocqueville observed (1945, 2:104-106), Americans perceive their society as built $u p$ of family units. In this sense, Americans define their society as a collection of voluntary social contracts, a natural law of sorts. In the conclusion to his study of American kinship, Schneider (1968:109) develops an equivalence between Americans' sense of law and the anthropological concept of culture-both reveal "the outcome of the action of human reason on nature" and resolve "the contradictions between man and nature."

In identifying Americans' view of society as a "legal" view, it is important to qualify (as Schneider does) the sense in which it is legal. It can be called a legal vision if law is, in fact (which is to say, in theory), the sum of private contractual promises. It can be called a legal vision if the law is what the people say it is- "what the most do" (Hoebel 1968:15). It is a legal vision if law and custom are held to be one and the same, and if the population is egalitarian, homogeneous, or at least capable of consensus. The vision of the law that Schneider shows Americans to hold assumes that all people are equals, agents of the law by their very actions in relation to other people, through the media of their respective social roles. This view of law turns simultaneously toward both nature and society, as Unger (1975:19) elucidates in his essay on the consciousness of the liberal state:

The dominant consciousness in the liberal state includes a characteristic view of the relation between man as an agent or a thinker and the external world, between man and his fellows, and between man and his work or social place. With respect to the first, it emphasizes the subjection of nature to human will as the idea of action and the choice of efficient means to given ends as the exemplary procedure of reason. With regard to the second, it underlines the separateness of person, the artificial character of society, and the ties of reciprocal need and hostility among individuals. As to the third, it focuses on the ambivalent value of work as both a manifestation and a surrender of personality.

Unger's analysis suggests that if Americans view "law" as the name of some aggregate contractual connection among themselves, it is a con- 
tractual connection mandated by nature-and exalted in its domination of human nature.

A popular attitude in the United States holds that ordinary life is "legal"-in that it is ordered or to the extent that it is ordered (or presumed to be). It is important to note that this externalization of the reciprocal, contractual aspect of social relations implies that order is never implicit in relations, but always applied to relationships as a form of self-control or control over others. Hopewell's Baptists ascribe this order to God's word, but other populations bring secular concerns to their images of social order. In his community study, Engel (1984) shows some of the practical consequences of this attitude in the everyday process of social classification: people in Sander County see troublemakers and litigious groups as people for whom the ordinary bonds of the natural legal order are not effective or not sufficient. Specifically, it is personal-injury disputes that generate anxieties over litigiousness in Sander County, not contract disputes (ibid., p. 575): “Duties generated by socially imposed obligations to guard against injuring other people were seen as intrusions upon existing relationships, as pretexts for forced exchanges, as inappropriate attempts to redistribute wealth, and as limitations upon individual freedom." Engel's study suggests that, in the eyes of Sander County residents, concerns about litigiousness channel diffuse anxieties about the community's increasing pluralism. Hopewell Baptists show a similar response in somewhat different terms; they see disputing and litigation as defining characteristics of the unsaved (Greenhouse 1982a and 1982b).

Given Americans' popular understanding of the law as the sum of their society's functional and organic qualities, it is not surprising that Americans should perceive conflict with some apprehension, as a sign of social dissolution. In this sense, the Hopewell Baptist imagery of damnation differs from that of others neither by kind nor by degree, but only in its religious referents. Yet if this is so, how does court use acquire its exceptional, even "antisocial" (Engle 1984:549), status? Why are courts seen as inappropriate remedies for social conflict? This attitude would seem paradoxical. The Baptists addressed this paradox by pointing to Jesus' sole authority. What concerns structure the secular variant of their thinking?

\section{Litigiousness as a Cultural Sign in the United States}

The source of the paradox appears to lie in a central tension in Americans' long-standing conception of official law, and that is its competitive 
relationship with the unofficial natural law described above. It is as if courts do not augment society's inherent legality, but violate or preempt it. Society may be legal by definition, but this legality somehow excludes the bench and the bar. What constitutes this abrupt shift away from natural-law imagery when Americans face their own legal institutions? Miller (1965:104) suggests it is the scholasticism of the law, its "beguiling mystique" that (in a popular view) severs the law from the society it claims to serve. Miller's observation is helpful in sharpening the sense in which the redundancy of legal institutions is negative rather than positive, competitive rather than supplementary. His reference to the subversive "sophistication" of the official law suggests the terms in which Americans view the law's "textuality" - that is, the textual aspects of the law. Because most Americans never experience litigation, this textuality is somewhat hypothetical, a fact that gives its terms a certain arbitrariness and breadth. Is one source of Americans' traditional ambivalence about the law to be found in their rejection of the law's textual character? Some contrastive consideration of the narrative discourse of everyday life suggests that this is the case.

In everyday life, social roles are essential, not only in organizing society but also in giving it its legal quality (Schneider 1968; Warner 1962). In the United States the discourse of everyday life is performed in a rather formal sense-that is, it is the form of life that has public meaning. ${ }^{8}$ Indeed, the colloquial question "What are you going to be when you grow up?" is readily understood even by small children as an inquiry about their occupational goals. Doing and being merge. In some general sense, it seems likely that part of Americans' resistance to the idea of law in their everyday lives is a response to the insertion of the law's sophisticated textuality in the performance of society itself, a society organized by the harmony of nature and reason. Why, however, is the law's textuality unacceptable in ways that other forms of textuality (e.g., prayer, to take an example from the ethnographic discussion) are not?

Here the work of anthropologists concerned with language is particularly helpful. If ongoing social life is conceptualized (as ethnographers suggest it is) as a system of performed roles, it is important to observe that, as performances, roles have genres, points of view, and audiences. Such "generic" social roles can accumulate in a single individual (e.g., mother, wife, and lawyer), but they do not merge there.

8I borrow the distinctions between discourse and narrative, performance and text, and form and substance from Chatman 1978:26. 
The individual is crosscut by their multiplication. ${ }^{9}$ Hence, Americans worry about family obligations conflicting with the requirements of the workplace, or ethnic identity competing with national identity, and freedom compromising equality. These are competing genres that are felt as challenges to individuals and to society. Individuality itself, however, is not a generic role in this sense. Individuality defines the relationships between a person and his own generic attributes. An individual is in that sense unique, but individuality also entails identifications with others whose roles are counterparts. Varenne's (1984:242-243) analysis of pronouns in American English leads him to conclude that the use of "we" expresses the politics of identification with a speaker's audience. Because personal identity is a cluster of generic roles, uses of "I," "you," and "we" elide fairly easily, as Varenne shows.

Varenne's discussion of the first person (singular and plural) involves at one point a contrast to what he calls "bureaucratic" speech-the third-person singular and plural that marks a political distinction between the speaker and his subject. This is the third person of administration and the law: "May it please the court . . ." or "Yes, Your Honor." The impoliteness of "I-you" forms in legal contexts emphasizes the extent to which "you" is the implied audience in ordinary narrative discourse, as well as the extent to which "I-you" involves a relationship that is qualitatively different from "I-he" (for example). Varenne (ibid., p. 244) concludes: "Western ideology . . . is best characterized not so much by its 'individualism' as by the institutions that it constructs as it tries to deny the relevance of a holism that it is in fact experiencing." The relevance of this important observation to the subject of this chapter is in its suggestion that the experience of authority is an experience of hierarchy and that, while authority/hierarchy can be canceled or denied in the performance of ordinary formal discourse, appeals to the law make that denial problematic. Litigious Americans, who invoke and invite the intervention of a third party into the "I-you" discourse of everyday life, violate the unspoken proscription against introducing hierarchy into private relationships.

Arno considers another aspect of the capacity of legal language to

9Parsons (1970:142-143) offers a vivid example of the way social roles divide an individual into conflicting components in his discussion of the traditionalambivalence Americans express concerning married female schoolteachers: "If the differentiation between what may be called the maternal and the occupational components of the feminine role is incomplete and insecure, confusion between them may be avoided by insuring that both are not performed by the same persons. The 'old maid' teacher of American tradition may thus be thought of as having renounced the maternal role in favor of the occupational" (emphasis added). 
reorder social relationships. He analyzes official law as a "conflict discourse" (Arno 1985:42), and his discussion maps the impact of the law's "control communication" on the "structural communication" of everyday life. The language of the law is not only a different text, it actively transforms the structure of ordinary life (ibid., p. 45): "By bringing the problematic relation within its own terms of reference, control communication [brings] about substantive ordering, and that is precisely its overt function."10

These linguistic analyses suggest that a central dimension of the competitive stance of the official law is its authority. It is not that the law has an illegitimate authority, or that some other institutional arrangement might be preferable; as for Hopewell's Baptists, it is the fact of human authority that is at issue. ${ }^{11}$

In effect, Americans seem to hold two views of the law. The ethnographic and historical literature suggests that Americans hold a natural-law philosophy (described above) when the question is the functioning structure of society itself, but when the question turns to the nature of official law, Americans are positivists. To put this another way, Americans may see society as intrinsically ordered by collective contractual arrangements (hence its legal quality), but they simultaneously see official law as rules imposed externally by elite institutions. (For a succinct contrast of these two philosophies, see Unger 1975:72.) The natural-rights theorizing of Americans suggests that Americans identify with the law and view its use in a positive light. On the other hand, their positivist theorizing suggests that confrontations with the law are likely to be risky encounters on almost literally unfamiliar territory-in a strange language, around strange principles devised by strangers. Indeed, statistical and ethnographic studies of Americans' use of the courts reflects this ambivalence, as disputants either litigate or avoid çonfrontations altogether (Buckle and Thomas-Buckle 1981; Nader 1980; Merry 1982). The important point for the purposes of this chapter is that Americans hold these two views simultaneously and apply them to two

${ }^{10}$ For a sociolinguistic analysis of a religious institutional setting, see Zaretsky 1974: 166-219.

${ }^{11}$ Americans' ambivalence on authority is an old theme in social commentary on the United States. See, e.g., Tocqueville 1945 and Kammen 1973:157-165, and for a modern ethnographic perspective see Fitchen 1981:67 on the attitudes of rural white men toward responsibility on the job: "To accept a position of authority over others is thought to invite jealousy, resentment, and certain criticism. [Quoting an informant]: 'My husband wouldn't want to be in the middle that way. He'd catch heck from his boss above him and he'd catch heck from the guys below him. No, he'd rather be one of them [the crew of laborers], even if he has to pass up a higher salary.'" 
different populations: the regular folk who "get along" and "litigious Americans."

This ambivalence is expressed in the discourse of authority and its place in social relations. As we have seen, to the extent that Americans resist the law in personal affairs, one aspect of the resistance is linguistic. Specifically, this resistance is aimed at the intertextuality of the official law and everyday life; it is a resistance that would cancel the discourse of official law altogether (indeed, in 1810 the Georgia legislature entertained a bill to prohibit the practice of law). The embedded imagery of the law as a genre of discourse is helpful to our discussion, because it sheds light on how litigiousness acquires some of its negative value in the cultural complex at issue here. To continue the notion of legal discourse in a metaphor, litigation is a form of apostrophe, ${ }^{12}$ a diversion of ordinary dyadic exchanges to some third party, an interruption of context. Culler's (1981:135) discussion of apostrophe focuses on the awkwardness of such obtrusive appeals: "[Apostrophes] may complicate or disrupt the circuit of communication, raising questions about who is the addressee, but above all they are embarrassing." Culler goes on to discuss the status of the voice in written literary forms, but a close analogy to his observation highlights the specific crisis of litigiousness: as apostrophe, its embarrassment is political. In turning aside to voice an appeal to agents who stand outside the problematic relationship, the plaintiff sets the outsider-the lawyer, the policeman, the judge-above his neighbor. The embarrassment of apostrophe in social relations deemed to be already legal is the sudden overturning of a supposed relation of equality by a relation of hierarchy and authority. From this perspective, it is the possibility of equality's transformation into hierarchy that makes litigiousness seem to be the very unmaking of the Revolution. ${ }^{13}$

${ }^{12}$ Culler (1981:135) credits Quintilian with the definition of apostrophe as "a diversion of our words to address some person other than the judge." In my application of the term to ordinary conversational contexts, the "judge" would refer to one's conversational partner.

${ }^{13}$ Gorer (1948:39-40) also recognized the obtrusiveness of the invocation of norms in ordinary social relations, but he expressed what I am calling their apostrophic nature in terms of gender: "The idiosyncratic feature of the American conscience is that it is predominantly feminine. . . . Duty and Right Conduct become feminine figures. . . . The fact that rules for moral conduct are felt to emanate from a feminine source is a cause of considerable confusion to American men. They tend to resent such interference with their own behavior, and yet are unable to ignore it, since the insistent maternal conscience is a part of their personality." Unless research demonstrates that concern with litigiousness is more prevalent among men, I prefer to read Gorer's analysis as a commentary on the ways in which his male informants symbolized otherness. 
What are the connections between the case of Hopewell's Baptists and other Americans? Drawing on an interdisciplinary literature concerning American patterns of disputing, the politics of identity, and culture, we can point to some parallels: their shared sense (expressed by Schneider) of the definition of society as a set of legal contracts. These contracts, or this legality, is not intrinsic to relationships, but is brought to themperhaps by virtue of citizenship, or by salvation, or by some other attribute. On this particular point, we might expect considerable diversity. There is also a second obvious parallel in the extent to which Hopewell's Baptists and those Americans who decry litigation by others condemn litigiousness as both a cause and a sign of social disintegration. Third, the negative valuation of disputing and litigation that both Hopewell Baptists and other (though certainly not all other) Americans express resides in the formal aspects of their discourse-in the creation and reproductions of generic categories of others, sometimes named, sometimes not, whose social predations are served by their allegedly inappropriate use of courts. The Baptists of Hopewell have used generic classifications to convey the meaning of litigiousness across the generations since the mid-nineteenth century; they remain in form but have changed in content. Today's concerns in Hopewell focus not on the antiCherokee, hard-line Democrats but on godless businessmen or selfabsorbed city people, and so on. These categories reiterate the generic forms of the outsider and the power elite, as well as the futility and sacrilege of confronting them.

The Baptist church is thriving in Hopewell, where the new temptations of affluence in the Sunbelt fuel a continuing felt need for salvation. This observation leads to a concluding point: to the extent that Americans worry about litigiousness, they share with Hopewell's Baptists a cultural vision that reveals at once a cultural model of society and a portrait of its enemies. The cultural model of society is, as we have seen, a harmoniously functioning web of contractual relationships among equals. The portrait of the enemy lacks a face-he might be one's neighbor, one's customer, one's client, or one's patient-but (and on this the portrait is clear) he has stolen the mantle of the king.

\section{Acknowledgments}

This paper is based on two years of research conducted in "Hopewell," Georgia, from 1973 to 1975 , and a short stay of several weeks in 1980 . 
The original research was funded by a National Institute of Mental Health Traineeship to Harvard University's Department of Anthropology; my return was funded by a Faculty Research Grant from the College of Arts and Sciences, Cornell University. I am very grateful to these sources, and to Paul Meade, for research assistance on the present chapter. I also express my appreciation to the sponsors and members of the Wenner-Gren Symposium, for which the first version of this paper was written. Special thanks are due to the conference organizers, Jane Collier and June Starr, for their constructive comments on that version.

\section{REFERENCES}

Arno, Andrew. 1985. “Structural Communication and Control Communication: An Interactionist Perspective on Legal and Customary Procedures for Conflict Management." American Anthropologist 87(1):40-55.

Batteau, Allen. 1982. "Mosbys and Broomsedge: The Semantics of Class in the Appalachian Kinship System.” American Ethnologist 9(2):445-466.

Bryant, Carlene. 1980. We're All Kin. Knoxville, Tenn.

Buckle, Leonard, and Suzann Thomas-Buckle. 1981. "Doing unto Others: Dispute and Dispute Processing in an Urban American Neighborhood.” In R. Tomasic and M. Feeley, eds., Neighborhood Justice, pp. 78-90. New York.

Chatman, Seymour. 1978. Story and Discourse. Ithaca, N.Y.

Culler, Jonathan. 1981. The Pursuit of Signs. Ithaca, N.Y.

Curran, Barbara A., and Francis O. Spalding. 1974. The Legal Needs of the Public. Chicago.

Engel, David M. 1984. “The Oven-Bird's Song: Insiders, Outsiders, and Personal Injuries in an American Community." Law and Society Review 18(4):549-579.

Fitchen, Janet M. 1981. Poverty in Rural America: A Case Study. Boulder, Colo.

Galanter, Marc. 1974. "Why the 'Haves' Come Out Ahead." Law and Society Review 9(1):95-160.

- 1983. "Reading the Landscape of Disputes: What We Know and Don't Know (and Think We Know) about Our Allegedly Contentious and Litigious Society." UCLA Law Review 31(1):4-71.

Gorer, Geoffrey. 1948. The Americans. London.

Greenhouse, Carol J. 1982a. "Looking for Rules, Looking at Culture." Man, n.s. $17: 35-53$.

- 1982b. "Nature Is to Culture as Praying Is to Suing." Journal of Legal Pluralism 20:17-35.

- 1983. "Being and Doing: Competing Concepts of Elite Status in an American Suburb.” In George Marcus, ed., Elites. Albuquerque.

- 1986a. Praying for Justice. Ithaca, N.Y. America. Lincoln, Nebr. 
Hoebel, E. A. 1968. The Law of Primitive Man. Cambridge, Eng.

Hostetler, John A. 1984. "The Amish and the Law: A Religious Minority and Its Legal Encounters." Washington and Lee Law Review 41(1):33-47.

Kammen, Michael. 1973. People of Paradox. New York.

Merry, Sally E. 1979. "Going to Court: Strategies of Dispute Management in an American Urban Neighborhood." Law and Society Review 13:891-926.

Miller, Perry. 1965. The Life of the Mind in America. New York.

Nader, Laura, 1980. No Access to Law. New York.

Nelson, William E. 1981. Dispute and Conflict Resolution in Plymouth County, Massachusetts, 1725-1825. Chapel Hill, N.C.

Parsons, Talcott. 1970. Social Structure and Personality. New York.

Peacock, James L. 1975. Consciousness and Change. Oxford.

Perin, Constance. 1977. Everything in Its Place. Princeton.

Phillips, Ulrich B. 1968. Georgia and State's Rights. Yellow Springs, Ohio.

Schneider, David M. 1968. American Kinship: A Cultural Account. Engelwood Cliffs, N.J.

- 1977. "Kinship, Nationality, and Religion in American Culture: Toward a Definition of Kinship." In J. L. Dolgin, D. S. Kemnitzer, and D. M. Schneider, eds., Symbolic Anthropology, pp. 63-71. New York.

Tocqueville, Alexis de. 1945. Democracy in America. 2 vols. New York.

Tomasic, Roman, and Malcolm Feeley, eds. 1982. NeighborhoodJustice. New York. Unger, Roberto M. 1975. Knowledge and Politics. New York.

Varenne, Herve. 1984. "The Interpretation of Pronominal Paradigms: Speech Situation, Pragmatic Meaning, and Cultural Structure." Semiotica 50(3/4):221-248.

Warner, W. Lloyd. 1962. American Life: Dream and Reality. Chicago.

Wills, Garry. 1979. Inventing America. New York.

Zaretsky, Irving. 1974. "In the Beginning Was the Word: The Relationship of Language to Social Organization in Spiritualist Churches." In I. Zaretsky and M. Leone, eds., Religious Movements in Contemporary America, pp. 166-219. Princeton. 
